\title{
Erratum to: Two early eudicot fossil flowers from the Kamikitaba assemblage (Coniacian, Late Cretaceous) in northeastern Japan
}

\author{
Masamichi Takahashi $^{1} \cdot$ Patrick S. Herendeen $^{2} \cdot$ Xianghui Xiao $^{3}$
}

Published online: 7 June 2017

(C) The Botanical Society of Japan and Springer Japan 2017

\section{Erratum to: J Plant Res}

DOI 10.1007/s10265-017-0945-1

In original publication of the article, the species name "Archaestella verticillatus" was published incorrectly throughout the article. The correct name is "Archaestella verticillata".

The online version of the original article can be found under doi:10.1007/s10265-017-0945-1.

Masamichi Takahashi

masamichi@env.sc.niigata-u.ac.jp

1 Department of Environmental Sciences, Faculty of Science, Niigata University, Ikarashi, Nishi-ku, Niigata 950-2181, Japan

2 Chicago Botanic Garden, 1000 Lake Cook Road, Glencoe, IL 60022, USA

3 Advanced Photon Source, 9700 S Cass Avenue, Argonne, IL 60439, USA 